\title{
RADIOCHEMICAL SEPARATIONS PLANT STUDY LIMITED MAINTENANCE-CASE VII
}

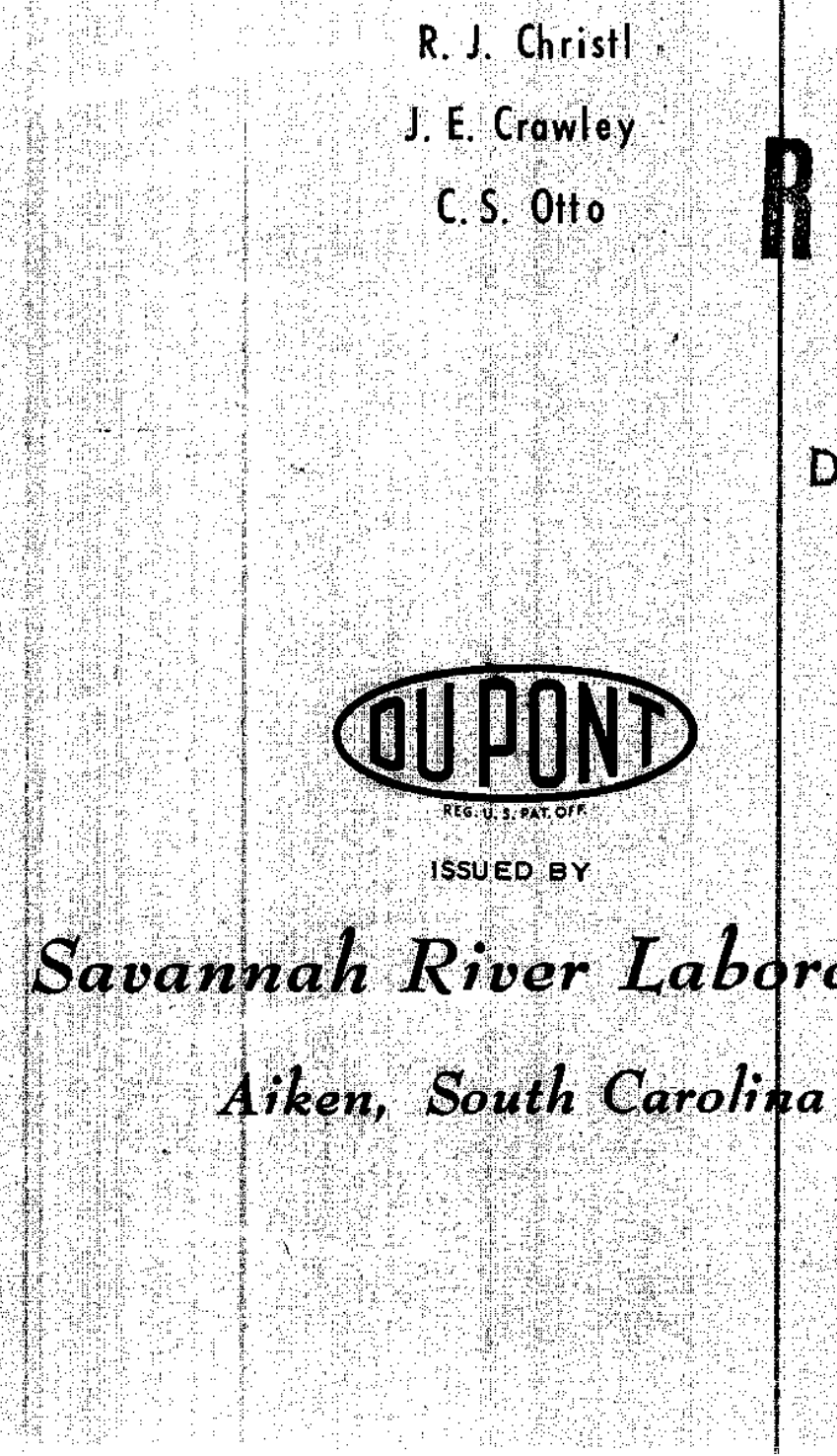




\section{LEG A L NOTICE}

This report was prepared as an account of Government sponsored work. Nefther the United States, nor the Commission, nor any person acting on behq if of the Commission:

A. Makes any warranty or representation, expressed of implied, with respect to the accuracy, completeness, or usefulness of the information cont ined in this report, or that the use of any information, apparatus, method, or process discloped in this report may not infringe privately owped rights; or

B. Assumes any Habtities with respect to the use of, or for damages resulting from the use of any lifformation, apparatus, method, or process displo sed in thil report.

$A_{B}$ used in the above, "person acting on behalf of the Commiselon" includes any employee or contractor of the Commission, or employee of guch contractor, to the extent that such employee or contractor of the Commisston, or employee of euch contractor prepares,

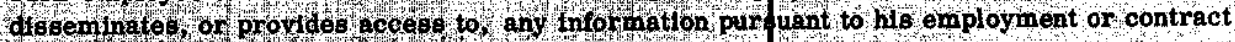
With the commission, or hisemployment with such contraptor.
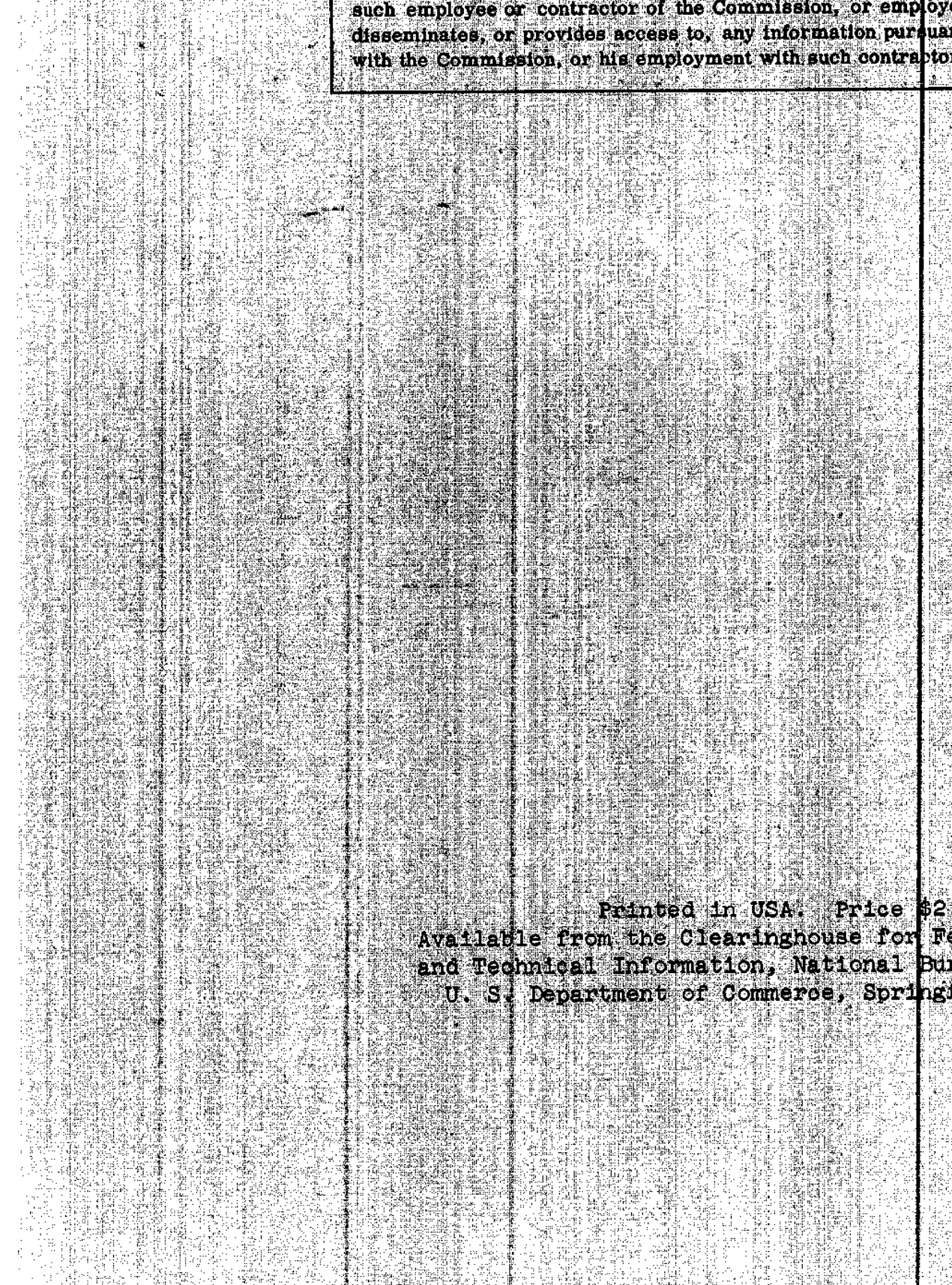


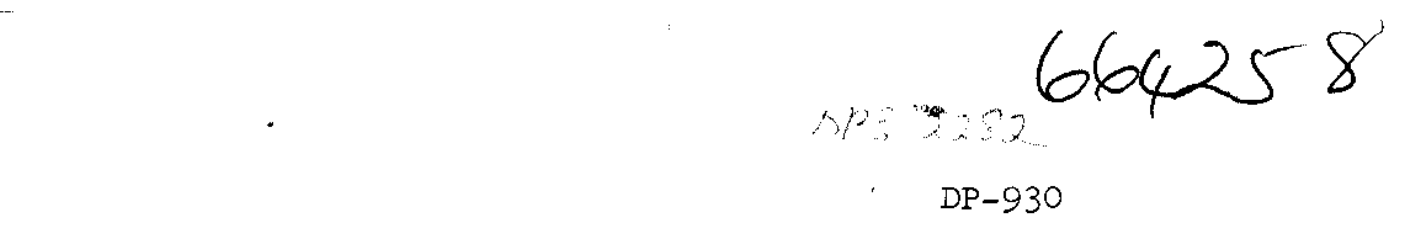

Chemical Separations Processes

for Plutonium and Uranium

(TID-4500, 32nd Ed.)

\author{
RADIOCHEMICAL SEPARATIONS PLANT STUDY \\ Limited Maintenance - Case VII \\ by \\ Robert J. Christl \\ John E. Crawley \\ Clifford S. Otto \\ Manufacturing Division - Process Section \\ wilmington, Delaware \\ September 1964
}

Issued by

E. 1. DU PONT DE NEMOURS \& COMPANY

SAVANNAH RIVER LABORATORY

AIKEN, SOUTH CAROLINA

CONTRACT AT(07-2)-1 WITH THE

UNITED STATES ATOMIC ENERGY COMMISSION 


\begin{abstract}
A conceptual design and estimate for a "limited maintenance" radiochemical separations plant for processing irradiated nonproduction reactor fuels have been prepared to supplement the cases presented in Report DP -566 .
\end{abstract}




\section{CONTENTS}

$\underline{\text { Page }}$

I. SUMMARY

A. General

B. Conclusion

II. DISCUSSION

A. General 6

B. Design Basis 6

$\begin{array}{ll}\text { C. Design Procedure } & 7\end{array}$

III. DESCRIPTION OF FACILITY 7

$\begin{array}{ll}\text { A. General } & 7\end{array}$

B. Process Equipment Design Concept 8

C. Separations Building Arrangement 8

D. Services 10

E. Plot Plan 11

IV. ESTIMATE 11

V. COMPARISON OF CASES I AND II WITH CASE VII 12
A. Cases I and VII
12
B. Cases II and VII
C. Operating Costs 


\section{LIST OF EXHIBITS}

Exhibst

$\underline{\text { Page }}$

1 Case VII - Plant Material Flow Dlagram

2 Case VII - Simplified Process Flow and Instrument Diagram

3 Case I - Simplified Process Flow Dlagram

4 Case I - AlI Buildings - Area Isometric Plot Plan

5 Case I - All Bulldings - General Arrangement Process Facilities

6 Case I - Building No. 13 Canyon Equipment Arrangement

7 Case VII - Bullding No. 13 Canyon Arrangement

8 Case VII - Bullding No. 13 Section Sheet 1

9 Case VII - Bullding No. 13 Section sheet 2

Case VII - Bullding No. 13 Section Sheet 3

II Case VII - Typical Agitator Drive and Bulge Arrangement

Case I - All Buildings - Air Flow Dlagram

13 Case VII - Bullding No. 13 - Bullding Arrangement

14 Comparison of Estimated Costs 


\section{RADIOCHEMICAL SEPARATIONS PLANT STUDY \\ Limited Maintenance - Case VII}

\section{SUMMARY}

A. General

This work, requested in AEC Directive $28(\mathrm{AP})$, consisted of studies and an evaluation estimate for a 10-ton-per-day Radiochemical Separations Plant.

This study and estimate supplement the $s i x$ previous Radiochemical Separations Plant Study cases requested by AEC Directive $7(\mathrm{AP})$ and reported in DP-566. The same labor and material indexes were used in preparation of all estimates so that they can be compared directly. The estimates contain no escalation allowances for labor and material.

The principal differences between this case and the Base Plant Case I are the features of "Ilmited maintenance" and greater use of in-line instrumentation. Raw metal feed clarification was also eliminated as in the case II - Contact Maintenance Plant.

The estimated cost for the total plant is $\$ 58,000,000$, as compared to $\$ 60,000,000$ for Case $I$, indicating a lower investment but at the expense of plant process flexibility and extended shutdown time in the event of major equipment fallure.

The major portion of the investment savings was realized In the separations facilities, the cost for which was lower than Case I by about 7 or 8 per cent.

B. Conclusion

A lower plant investment is indicated for the Case VII; however, it is still within the range of accuracy of the Case I estimate. More extensive design and development would be necessary to firmly establish a cost differential.

The annual cost of operating the plant is expected to be about the same as the cost of operating the contact Malntenance Plant (Case II), reported in DP-566 as being $\$ 6,380,000$. 


\section{DISCUSSION}

\section{A. General}

On May 14, 1959, the AEC by Directive $7(\mathrm{AP})$ requested the Du Pont Company to conduct engineering studles and prepare evaluation estimates for six different cases of Radlochemical separations plants for recovery of fissionable materials contained in irradiated fuel from power reactors.

A definition of these cases and results of the studies were reported in DP-566 is sued in March 1961.

The collection of data from a plant featuring "limited maintenance"* resulted in the request by the $\mathrm{AEC}$ on November 11, 1962, by Directive 28(AP), to add a Case VII to the RSPS (Radiochemical Separations Plant Study), which would incorporate (1) major design features of the "Ilmited malntenance" plant and (2) advances in U.S. technology developed since the RSPS report which were considered worthwhlle from the standpoint of reduced plant investment.

This report covers the engineering study and evaluation estimate for only the first phase of this work associated with incorporating "limited maintenance" features. Incorporation of advanced U.S. technology would require further study.

\section{B. Design Basis}

All of the feed material, process flows and final product for this Case VII are the same as for the DP-566 Base Plant Case $I$. The aluminum element cladding is removed chemically with an $\mathrm{NaOH}$ solution and the urantum core is dissolved in $\mathrm{HNO}_{3}$. The Purex process is used for separating uranium and plutonium from various impurities with the liquid-liquid extraction being performed in mixer-settlers.

\footnotetext{
*Limited Maintenance is taken to mean providing for the replacement of equipment with moving parts and some selected items without moving parts where susceptibility to fallure from wear, pluggage, or other factors is significant. All other equipment items and piping are to be designed and built to specifications which would make them likely to last indefinitely in the intended service. No provisions are made in the design to faclittate their repair or replacement.
} 
The plant is capable of processing, on a sustained basis, 10 tons* per day of irradiated uranlum-aluminum reactor fuels, having a maximum reactor exposure of $5,000 \mathrm{MWD} /$ ton and a minimum cooling period before processing of 180 days. The waste is stored underground in carbon steel tanks. The finished products leaving the plant consist of a 43 wt \% solution of uranyl nitrate, and a plutonium nitrate solution contalning 250 grams plutonium/liter.

The only variations in the design basis from the Base Plant Case I are those required by the substitution of the "limited maintenance" concept for remote maintenance and greater use of in-line instrumentation to reduce the requirement for process solution storage to obtain analytical results prior to further processing in the separations plant. A Plant Material Flow Diagram is shown in Exhlbit 1 and a Simplified Process Flow Diagram with location of in-line instrumentation is shown in Exhib1t 2. For comparison the Case I Simplified Process Flow Diagram is shown in Exhib1t 3.

\section{Design Procedure}

The design procedure followed in arriving at a description of Case VII sufficient for estimating was to make maximum use of the Base Plant Case I and develop only those parts directly affected by the defined concept chariges. This meant that no design work was necessary in areas such as the laboratory, sand filter, control room, change room, and office bullding.

In some cases buliding arrangement and equipment design were not developed in sufficient detall to establish compatiblilty with the base case ground rules; particularly with respect to ensuring at least $80 \%$ on-stream capability. It was assumed that such problems could be overcome in final design without major cost penalty.

\section{DESCRIPTION OF FACILITY}

\section{A. General}

The only facilities described herein are those which represent changes from Case I. Exhib1ts 4, 5, and 6 are taken from Case I and show the Plot Plan, bullding arrangement, and canyon equipment arrangement for case $I$.

\footnotetext{
*The 10-ton-per-day is based on natural uranium. The plant can also process higher enrichment but at a reduced capacity. $(\mathrm{DP}-566)$.
} 
Process Equipment Requirements

1. The raw metal adjustment tank, $2 \mathrm{~A}$ feed tank, and the head end centrifuge were eliminated from the process. The first two are considered unnecessary as a result of more accurate in-line analysis and application of continuous solution adjustment. The centrifuge was eliminated as it was in the contact maintenance Case II. The penalty of scheduled shutdown for IA mixersettler flush-out of solids would therefore have to be accepted.

2. A third dissolver and off-gas filter were added as installed spares. This unit was considered necessary to guarantee an acceptable on-line time with the anticipated relatively high maintenance of dissolvers.

\section{B. Process Equipment Design Concept}

All process equipment, such as mixer-settlers and blendIng tanks that require mechanical devices for successful operation, is designed to permit easy removal of mechanical parts. which, in turn, are driven by motors positioned outside canyon cell barriers.

Process equipment with heating elements, such as evaporators, is designed to operate under vacuum to reduce operating temperature and thereby to minimize corrosion. In addition, all hot walls of these vessels are fabricated of either heavy plate or extra heavy wall pipe.

The dissolver was designed to receive elements directly from shielding casks rather than belng charged by a remotely operated crane.

The use of all welded permanent type connections as process and service lines to process vessels completely eliminates the need for fabrication to close tolerance. This reduces somewhat the cost of conventional equipment such as tanks; however, opposed to this, there is the need to design and fabricate the equipment to a higher quality.

\section{Separations Building Arrangement}

The general arrangement of the separations building is specifically adapted to the "limited maintenance" concept. Exhibits 7 to 10 show plans and sections of this building. 
The principal part of the bullaing is the canyon, which contains the main process equipment. This section is never entered during processing operations and is separated from all adjacent operating areas by a 5 -foot concrete radiation shield or equivalent. Contamination is contalned within the canyon by maintaining air pressure several inches of water below that of surrounding areas so that leaks or openings will result in air flow toward the canyon.

The canyon is subdivided into three dissolver cells, one cell containing mixer-settlers and other extraction equipment, and one cell containing evaporation equipment. The three dissolver cells contain two on-stream dissolvers and one operating spare. They are separated from one another by 5 feet of concrete shielding so that maintenance work can be performed on one unit without interrupting normal production in the others.

The extraction area is separated from the evaporation area mainly for economic reasons since in doing so the ventilation air quantities can be greatly reduced. High air flow for cooling would otherwise be needed to keep solvent temperatures below the flash point.

The equipment pieces in the canyon are spaced closer together than they would be in a Contact Maintenance Plant because only infrequent and minor repairs are provided for in this concept, and no provisions are made to facilitate the removal and replacement of major equipmen't units.

The area below the canyon is considered a limited access operating area and contains mainly that equipment associated with the flush-out of canyon equipment.

The areas above and to the sides of the canyon are normal operating areas and except for the bulges* this area is considered free of contamination.

A11 electrical drives for canyon equipment (Exhibit II) are located on the canyon covers directly above the particular equipment served. The extended shafts pass through the concrete cover and directly to the process equipment, such as mixer-settlers and mix tanks. The shafts are provided with liquid seals to eliminate air flow through these points of entry.

*The bulges (Exhibit 11) are enclosures used to house selected small equipment items in radioactive service, such as jets, samplers, and instruments which are expected to require periodic maintenance. Their construction is such that, after decontamination of the equipment within them, the blological shield can be removed to permit essentially contact maintenance. 
Agitator removal is accomplished by using the service crane to lift the drive and a shield plug. The contaminated shaft and agitator are decontaminated in place and sprayed during removal through the cell cover, and are lifted directly into a shielded shipping box for transfer to the maintenance shop.

The charging of dissolvers is performed by lowering elements directly into the dissolver from a shlelded transfer cask. The cask is lifted from the element storage basin by the large charging crane and placed directly above the dissolver. Cask valves and dissolver cover valves are then opened and the element charged directly to the dissolver.

\section{Services}

\section{Instrumentation}

The basic premise for instrumentation to measure essential process variables is to provide equipment so designed and installed that all necessary functional tests can be made routinely without the need for access to the measuring assemblies, but with provisions for ready access under nonhazardous conditions when routine tests indicate need. Constant rate sample streams $w 111$ be brought to measuring assemblies located in shielded instrument bulges and then returned to the main process stream. Functional testing facilities will be located Just outside the bulges and means will be provided here for decontamination of equipment when maintenance access is required. Read-out signals only will be transmitted to a remote control center where alarm annunciators, recorders when required, and data logging equipment will be located. Only the remote control equipment required to make process adjustments will be located here. All manipulations for testing and maintenance of the measuring devices w1ll be located at the intermediate instrument stations away from the control center.

This approach permits use of minimum panel space at the main control center leading to optimum concentration of canyon process control equipment. This w1ll result in maximum operating labor effectiveness and savings to offset any additional investment costs which may be required due to this measurement and control concept. When equipment dependability has been established, further savings plus operating continuity advantages should be achievable through minimizing the necessity for routine sampling and laboratory analysis. 
Exhibit 2 Indicates various locations and types of measurements required to monttor the process for control purposes. Essentially all the devices indicated have been developed and can readily be adapted to the "Iimited maintenance" concept.

It is entirely possible that some additional operator labor savings can be achieved by bringing necessary intelligence and required operating facllities from process steps located outside the main separations area to the one main control center. This should be possible since the concentration of remote control gear permits an arrangement requiring relatively small control room area.

\section{Heating and Ventslating}

The only other major revision to service facilities from the Base Case is that assoclated w1th the reduced supply and exhausting of air from the canyon. The Case I flow diagram is shown in Exhibit 12. The canyon air flow was reduced by more than 50 per cent, thereby reducing in proportion the area of the sand filter and the diameter of the 400-foot exhaust stack.

\section{E. Plot Plan}

The rearrangement of bulidings which resulted from the revised separations bullding concept is shown in Exhib1t 13. In this rearrangement, the separation of regulated and nonregulated areas provided in earlier work was preserved but buildings were relocated to take better advantage of the smaller canyon building.

\section{ESTIMATE}

The comparison of estimated cost is shown in Exhibit 14. These estimates were prepared on the following basis:

1. Construction would be performed by a competent and qualified contractor under commerclal conditions.

2. The costs cover only those facllities located within the plant operating fence. That is, no allowance is included for facilities or maintenance of facilities located on land surrounding the operating area fence which may be owned or controlled by the plant operator.

3. The estimate is based upon the general site data given in DP-566. 
4. No costs are included for the purchase of land elther within or around the plant operating fence line.

5. No costs are included for bringing the service faclifties and utilities to the operating area fence line.

6. An average welghted wage rate of $\$ 3.14$ per hour has been assumed.

7. A Bureau of Labor Statistics Bulldings Material Index of 135 has been assumed - 1947 to 1949 Index taken as 100 .

8. A Bureau of Labor Statistics Metals and Metal Products Index of 155 has been assumed - 1947 to 1949 Index taken as 100.

9. No allowances have been included for premium time to complete construction on an accelerated schedule.

10. No allowance is included for advances in labor and materials costs.

11. Normal allowances are included for undeveloped design and for assistance to an operating group for placing the plant in operation.

12. No provision is included for prototyping or testing of special equipment.

13. Estimates on a conceptual design only. They are suitable for comparison and evaluation but not for authorization of construction.

\section{COMPARISON OF CASES I AND II WITH CASE VII}

A. Cases I and VII

The lower cost for Case VII results malniy from the reduced size of the canyon bullding and reduced canyon piping and equipment costs.

The lower plping cost results mainly from elimination of Jumpers and their connector blocks and balling which are a necessary part of the remote maintenance plant. Outside facilities such as filters, stacks, etc., were also reduced in cost because of reductions in canyon ventilating air quantities brought about by the smaller bullding and revised concept of air requirements. 
Extra machinery costs are reduced since it is not necessary to provide as many spares when many pleces of equipment can be more easily repaired in place than removed and replaced.

Cost increases were noted in areas such as chemical storage, cold feed preparation and decontamination solution storage. These costs result from the additional faclities required to decontaminate process equipment in place and then safely store or dispose of the resultant contaminated solution.

As to the relative operating advantage of the separate plants, this depends largely on the intended service of the plant. It is to be expected that the "Iimited maintenance" plant would have far less day-to-day maintenance, particulariy with elimination of the numerous canyon Jumper connections. This same feature would be expected to greatly reduce the canyon contamination resulting from leaks. However, when a major equipment failure occurs the time required to replace or repair it and the resulting production outage could be a major item.

The "limited maintenance" plant also adapts itself better to a set process which is not expected to change for a long period of time. The remote maintenance plant can be more rapidly adapted to major process changes involving production rate changes and even product changes.

The greater use of in-Iine instrumentation and resulting equipment reduction would probably be a major advantage for the "limited maintenance" case.

\section{B. Cases II and VII}

These cases are similar in that they both represent plants which require direct contact with canyon process equipment for repair or replacement.

The major difference which shows up as a sizable cost differential is the ability of the contact maintenance Case II plant to continue to be operable even through periods of repair to major equipment.

To attain this objective, it was necessary in Case II to duplicate a large portion of the process equipment and to install this equipment in a large number of individual celis.

The wall effect of the multiple cells, the added space for the installed spare equipment, and the large space provided on both sides of the canyon for shielded access to equipment resulted in a canyon cubage nearly twice that for the "limited maintenance" Case VII. 
The added canyon space also resulted in larger ventilating requirements and these together with the cost for extra process equipment constituted the major portion of the cost differential.

In both Cases II and VII, there was a savings over Case I in equipment plping by elimination of jumpers and an added cost allowed for storage of fresh and used contaminating solutions.

\section{Operating Costs}

The manpower requirements for the plant described herein will be essentially the same as those estimated for the contact maintenance plant (Case II) reported in DP-566, since the same services must be provided. While there might be some reduction in personnel assigned to the control laboratory because of the extensive use of in-Iine instrumentation, there must of necessity be an increase in the number of instrument mechanics and in the cost of decontaminating and repairing the instruments. The total personnel requirement would remain at about 285 , and the annual cost at about $\$ 6,380,000$. As stated in the original study, actual plant operating costs may vary $\pm 20 \%$ with individual items being subject to even wider variation. 


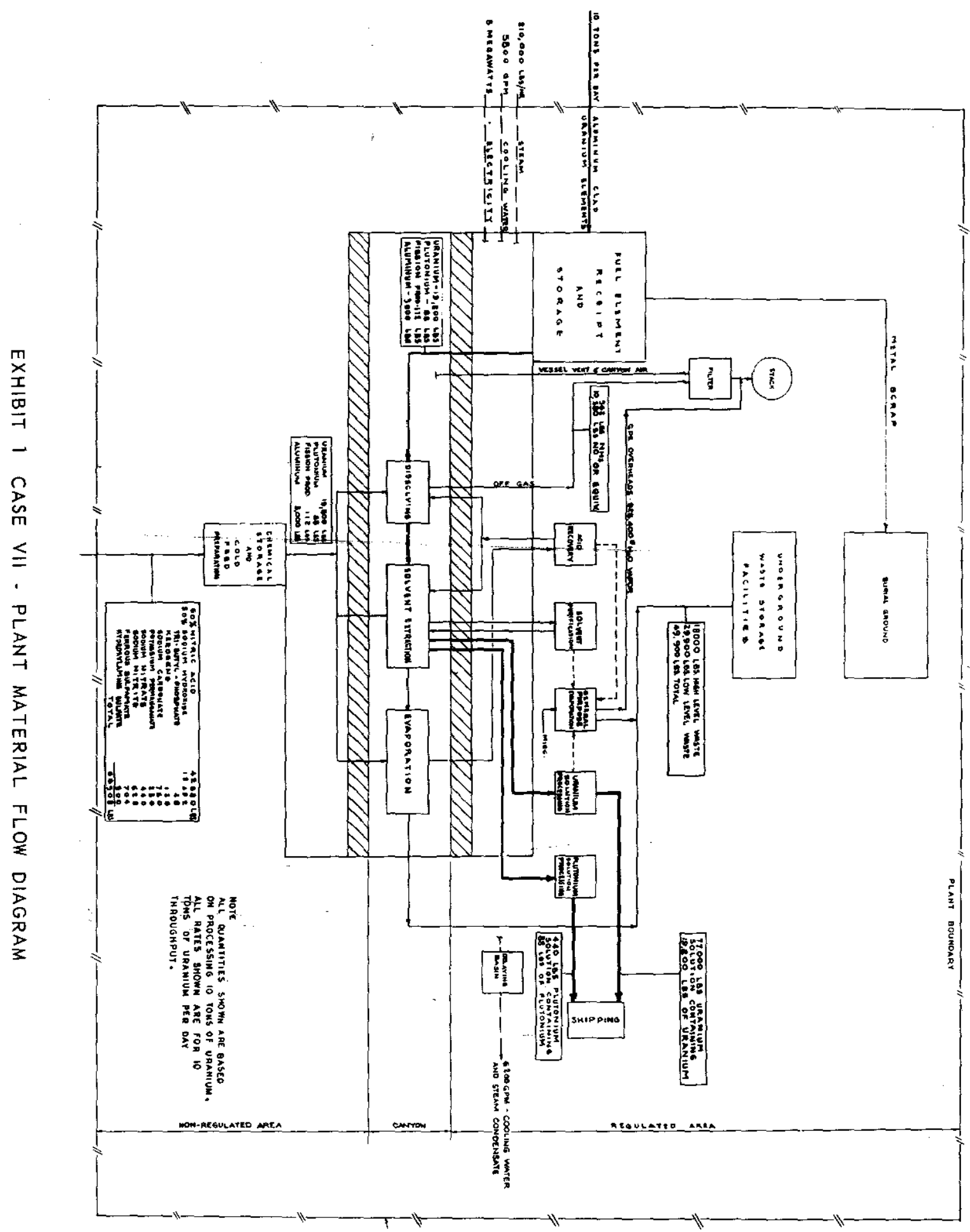




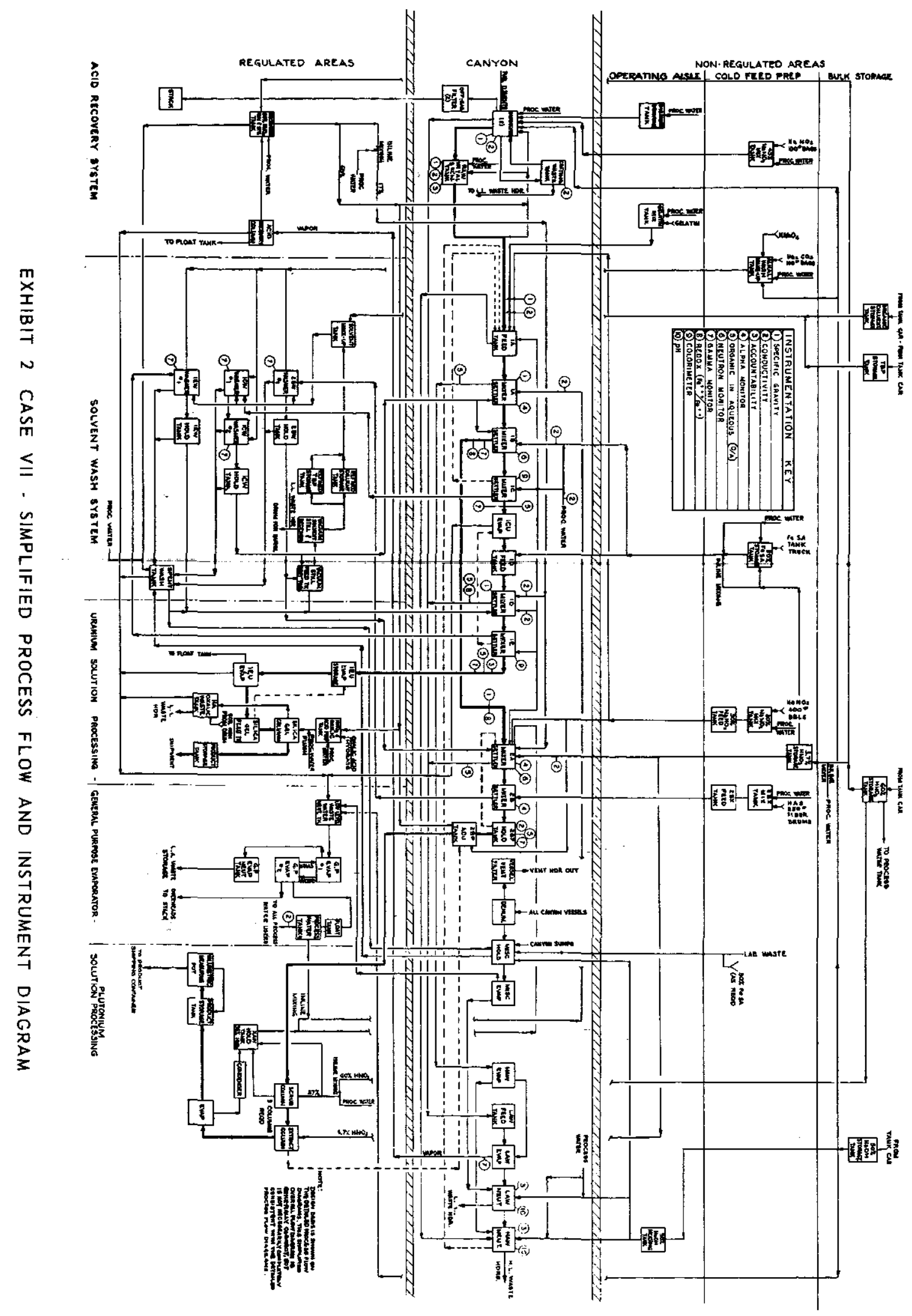




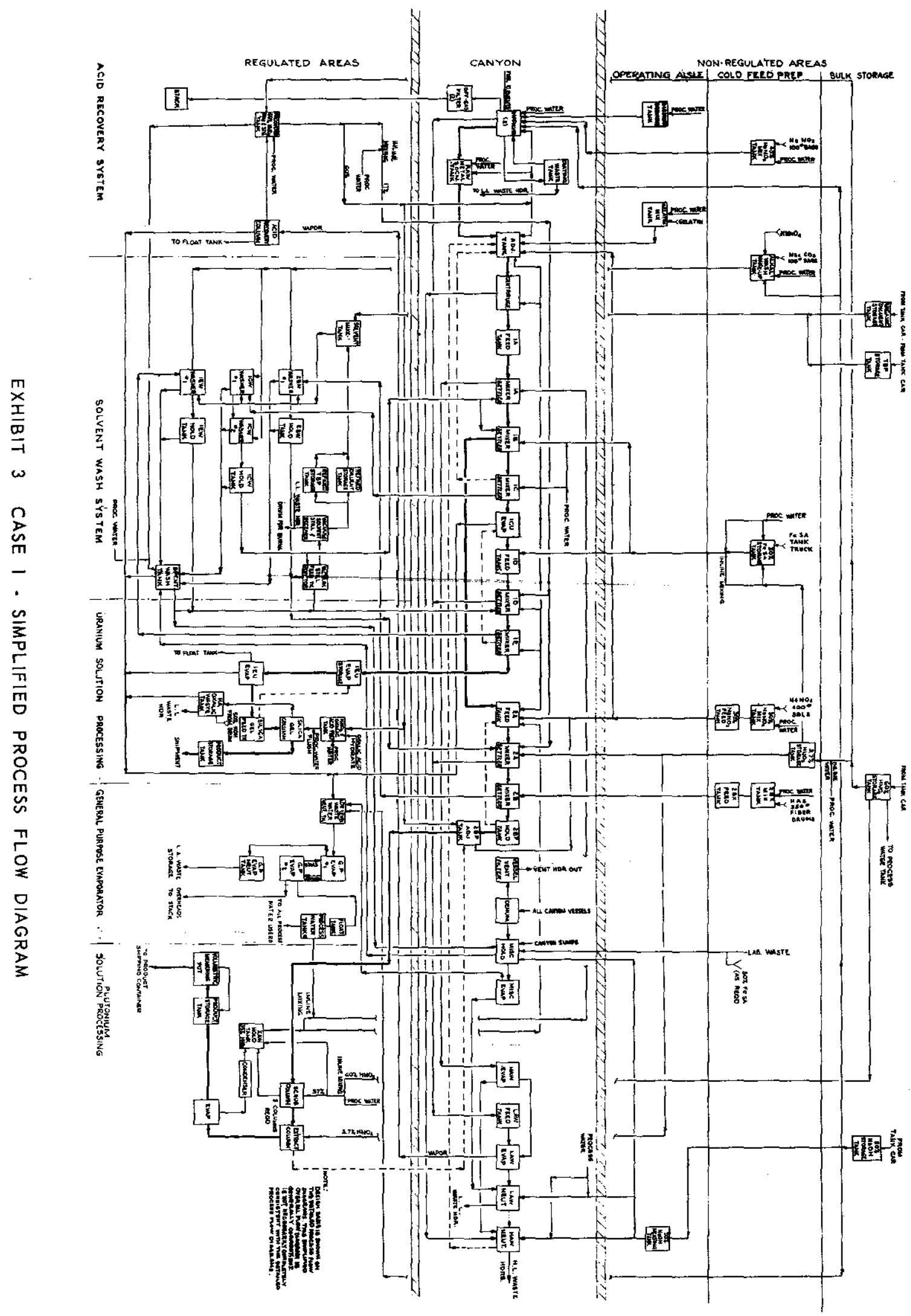




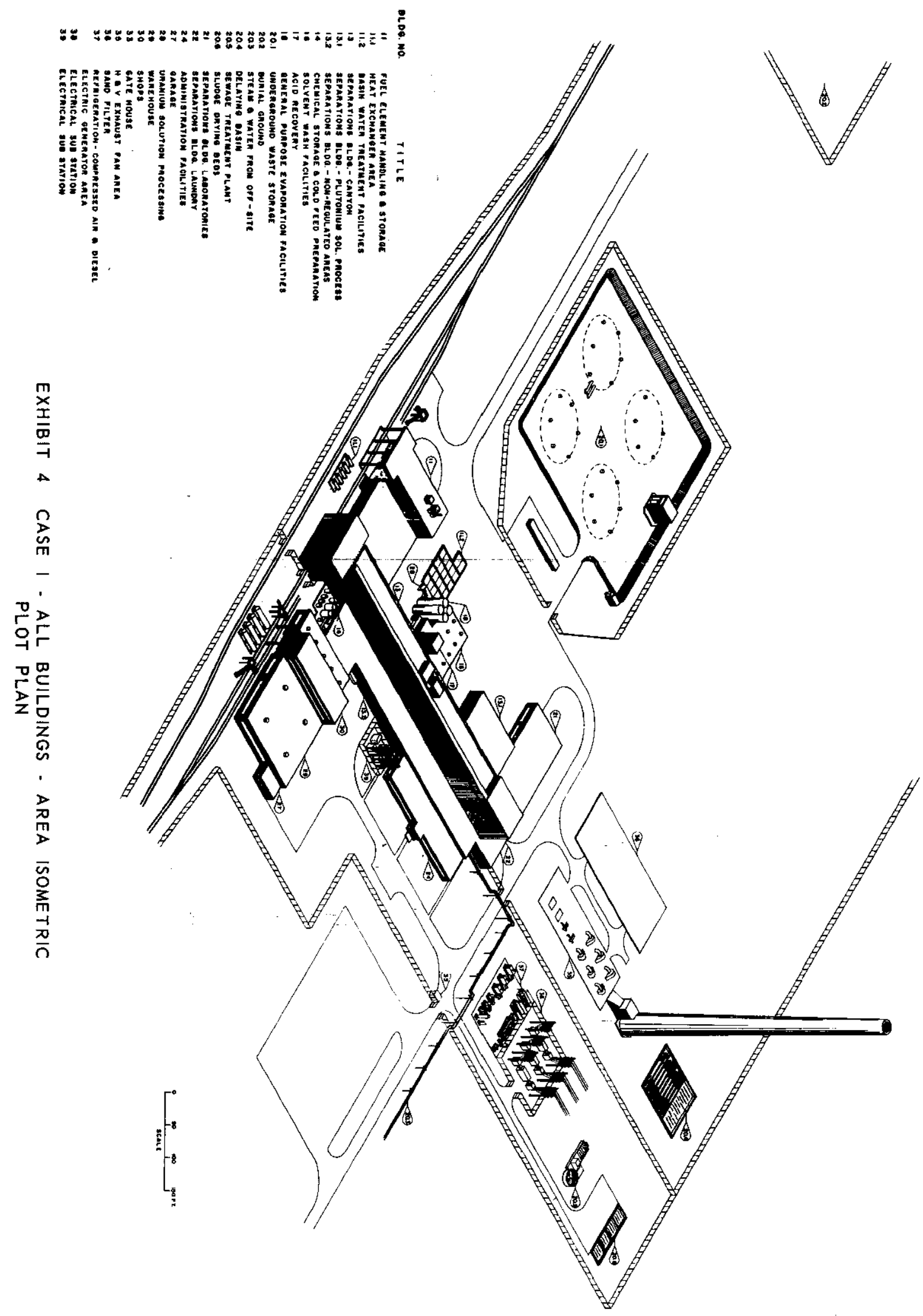




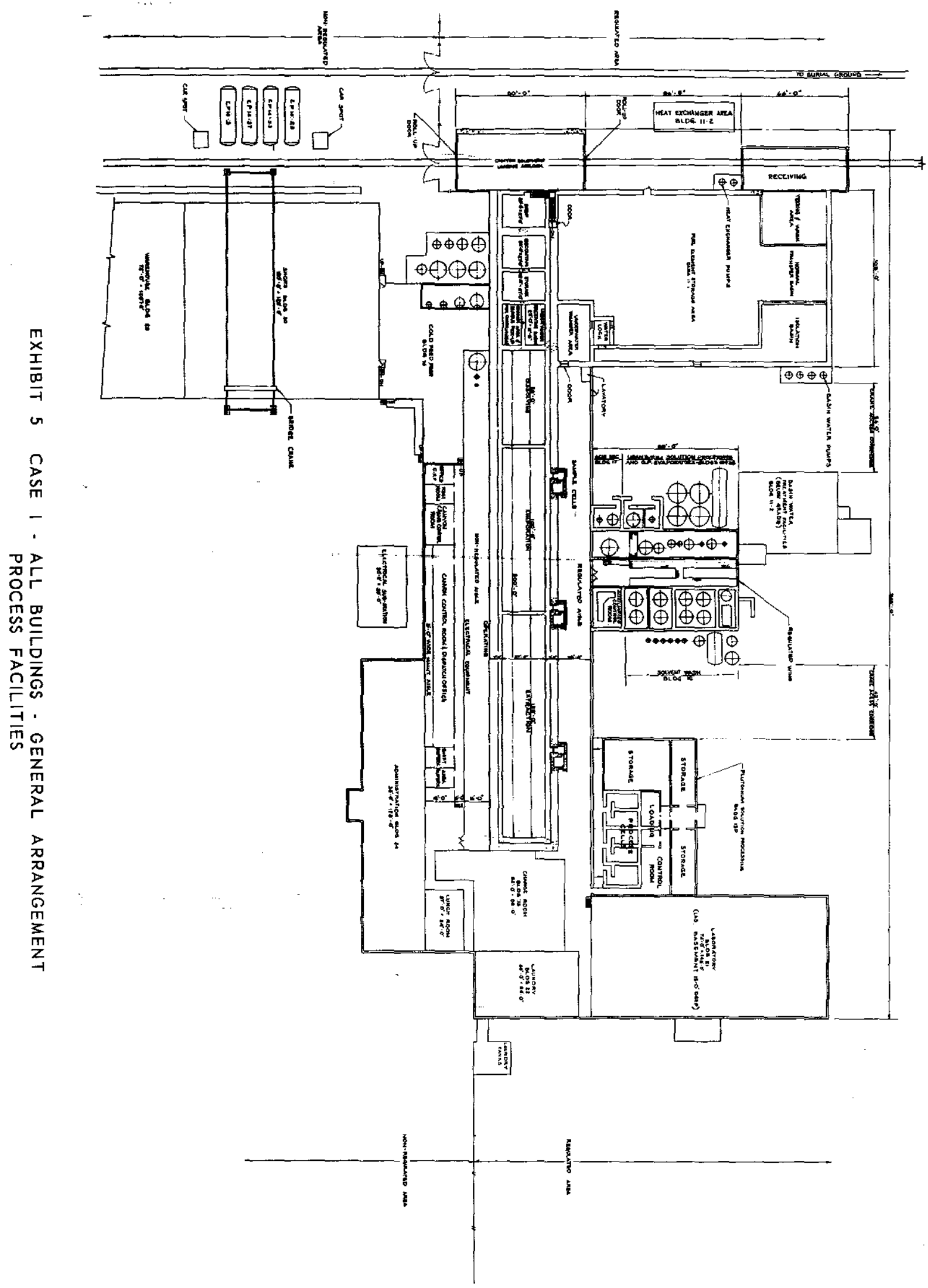




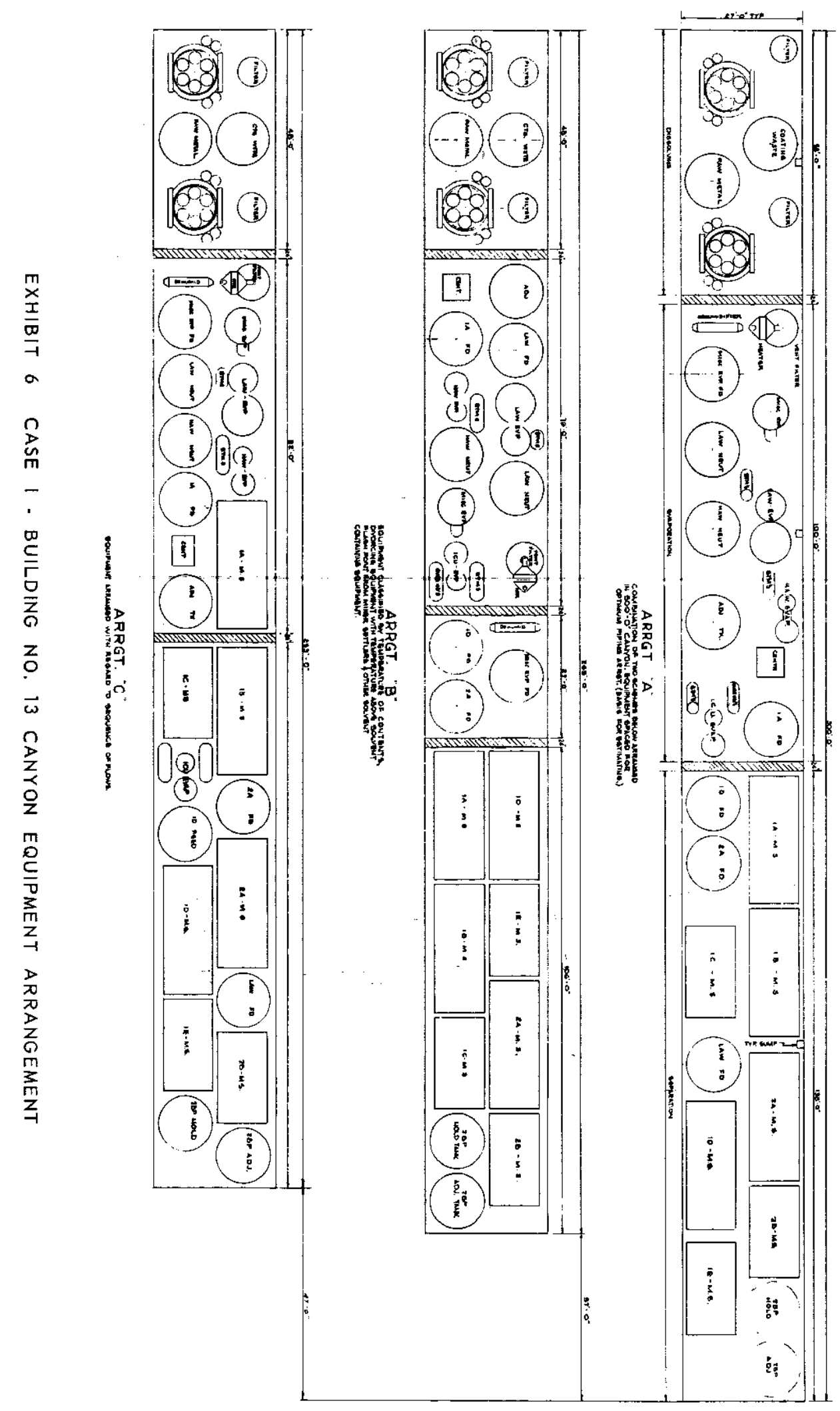




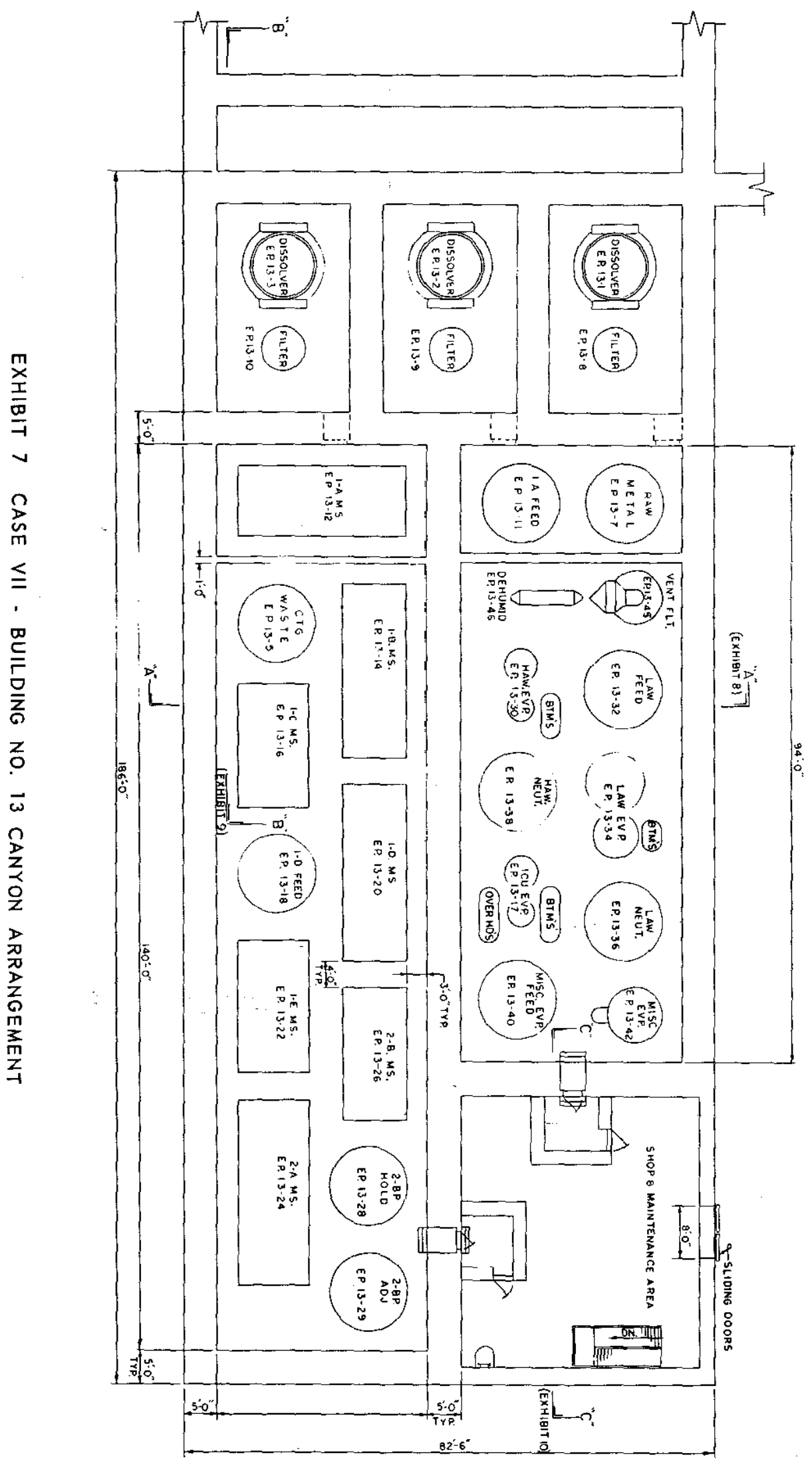




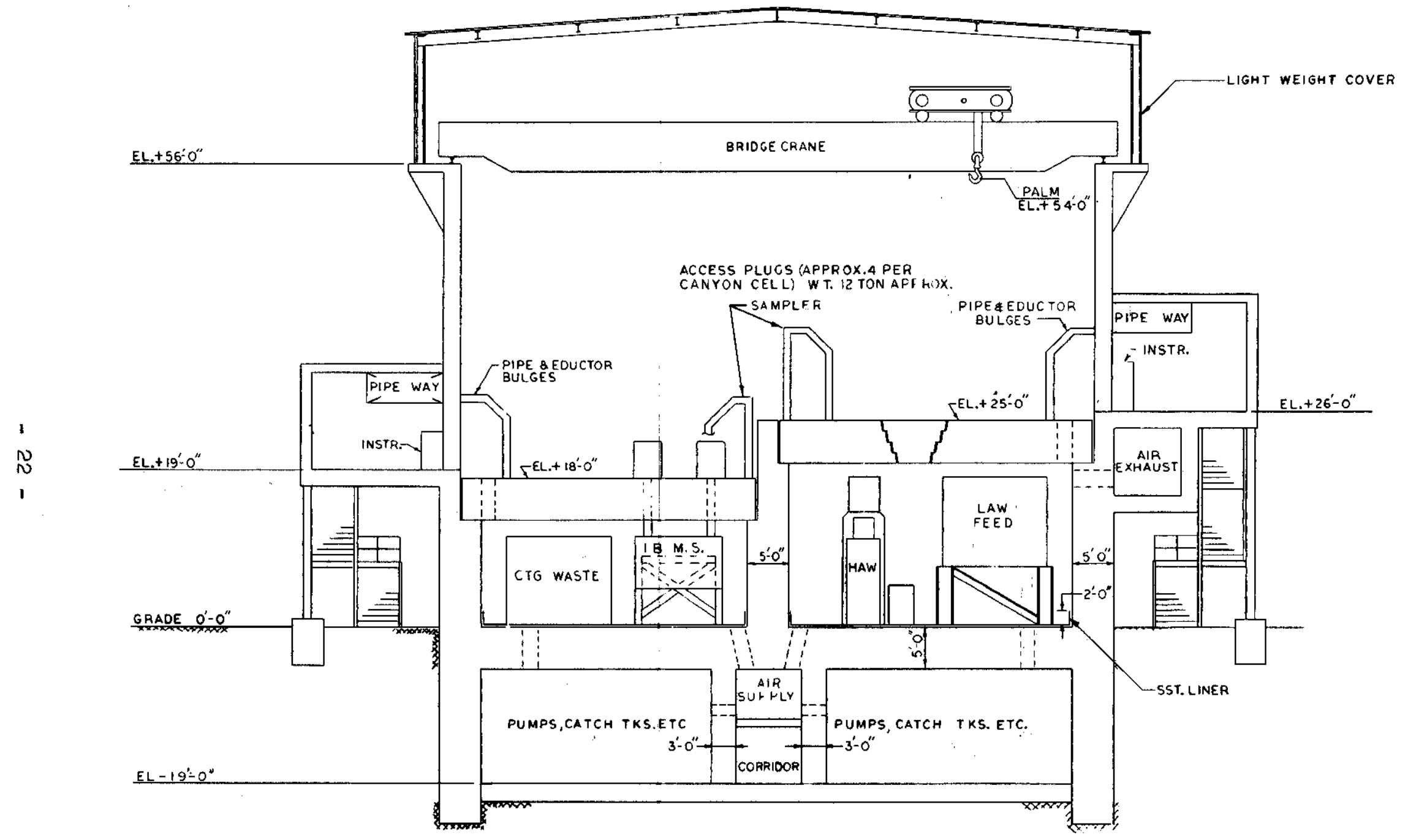

EXHIBIT 8 CASE VII - BUILDING NO. 13 SECTION - SHEET 1 


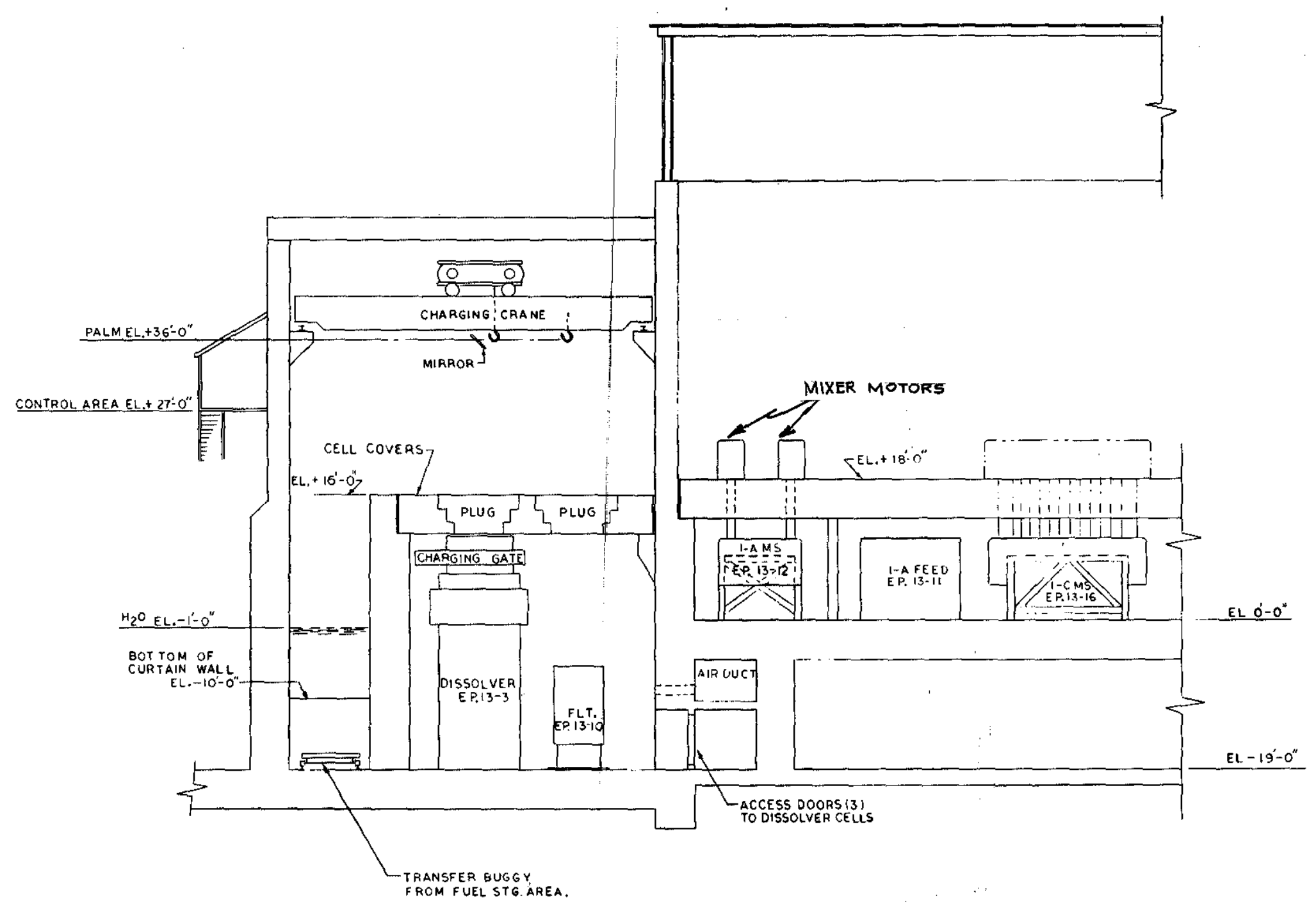

EXHIBIT 9 CASE VII - BUILDING NO. 13 SECTION - SHEET 2 


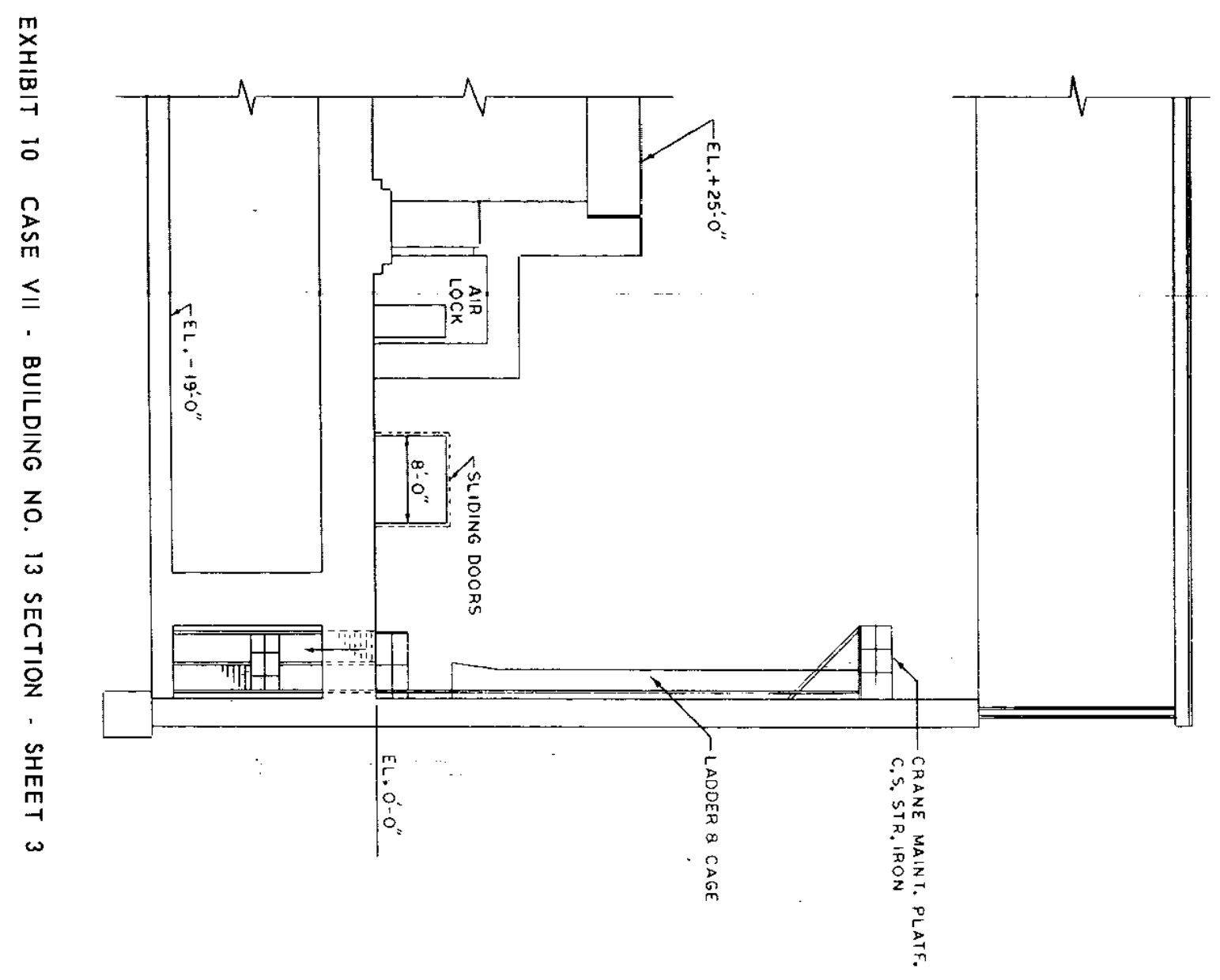




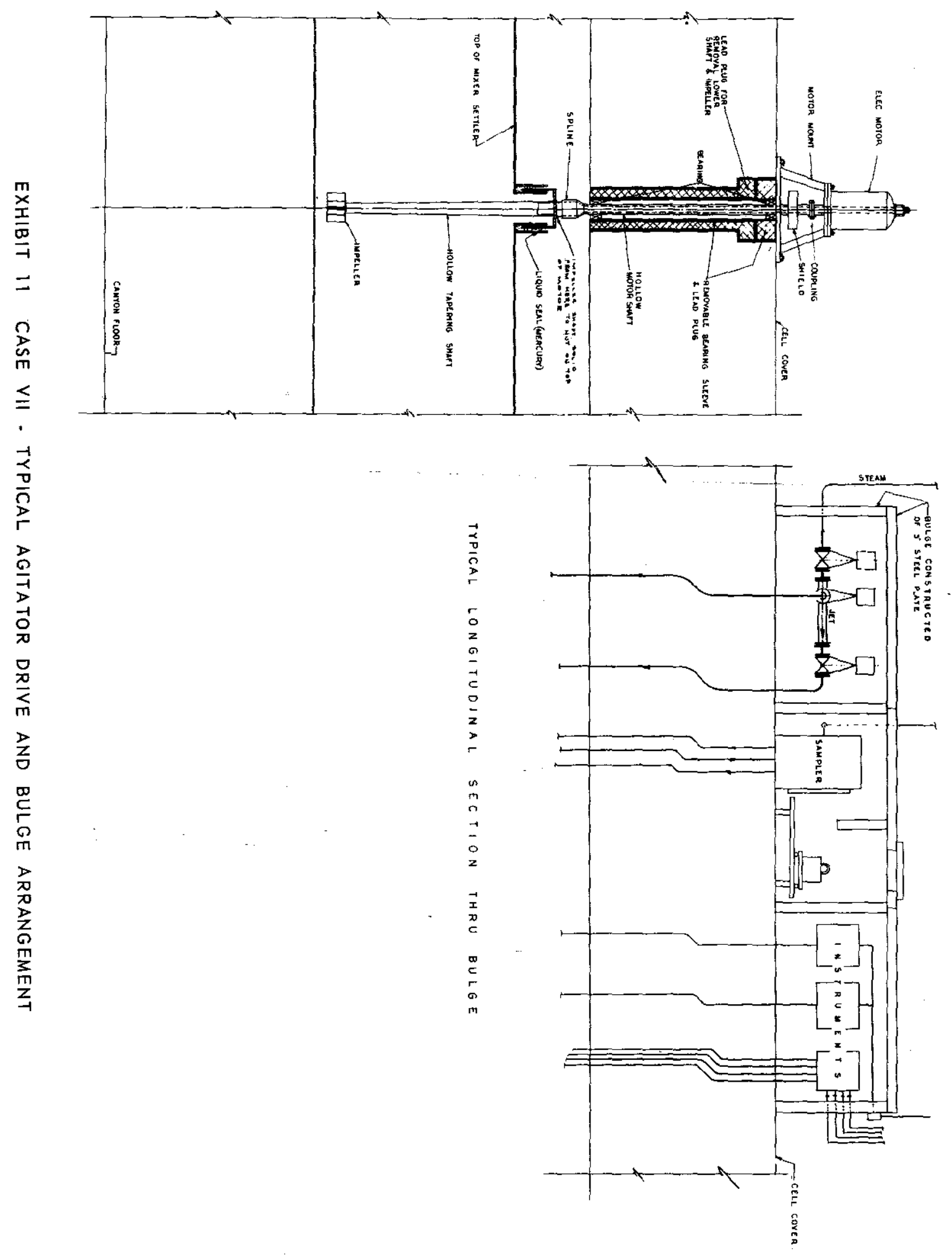




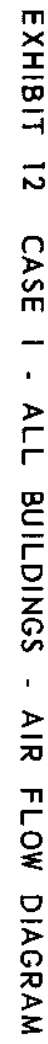
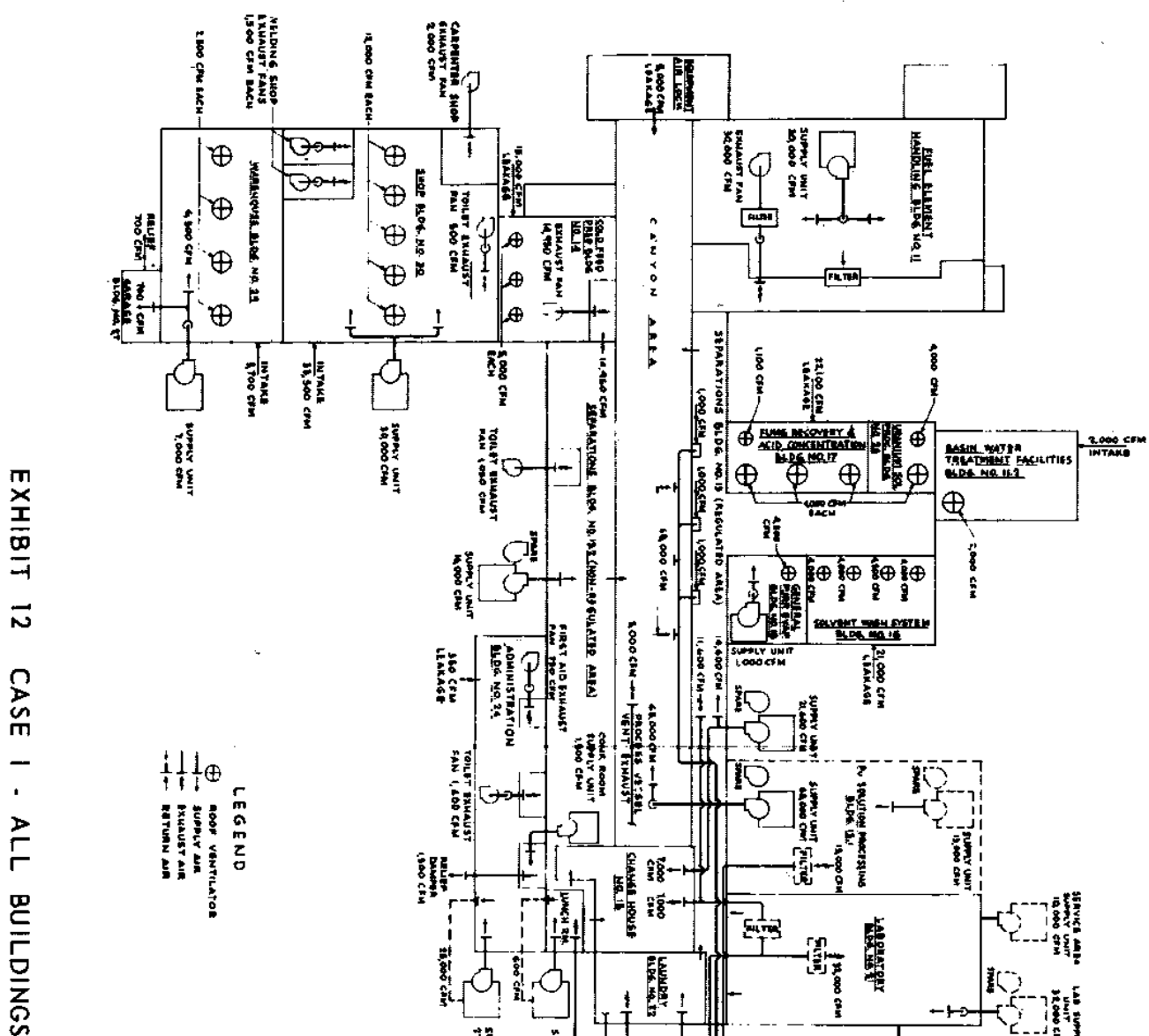
政

旅 


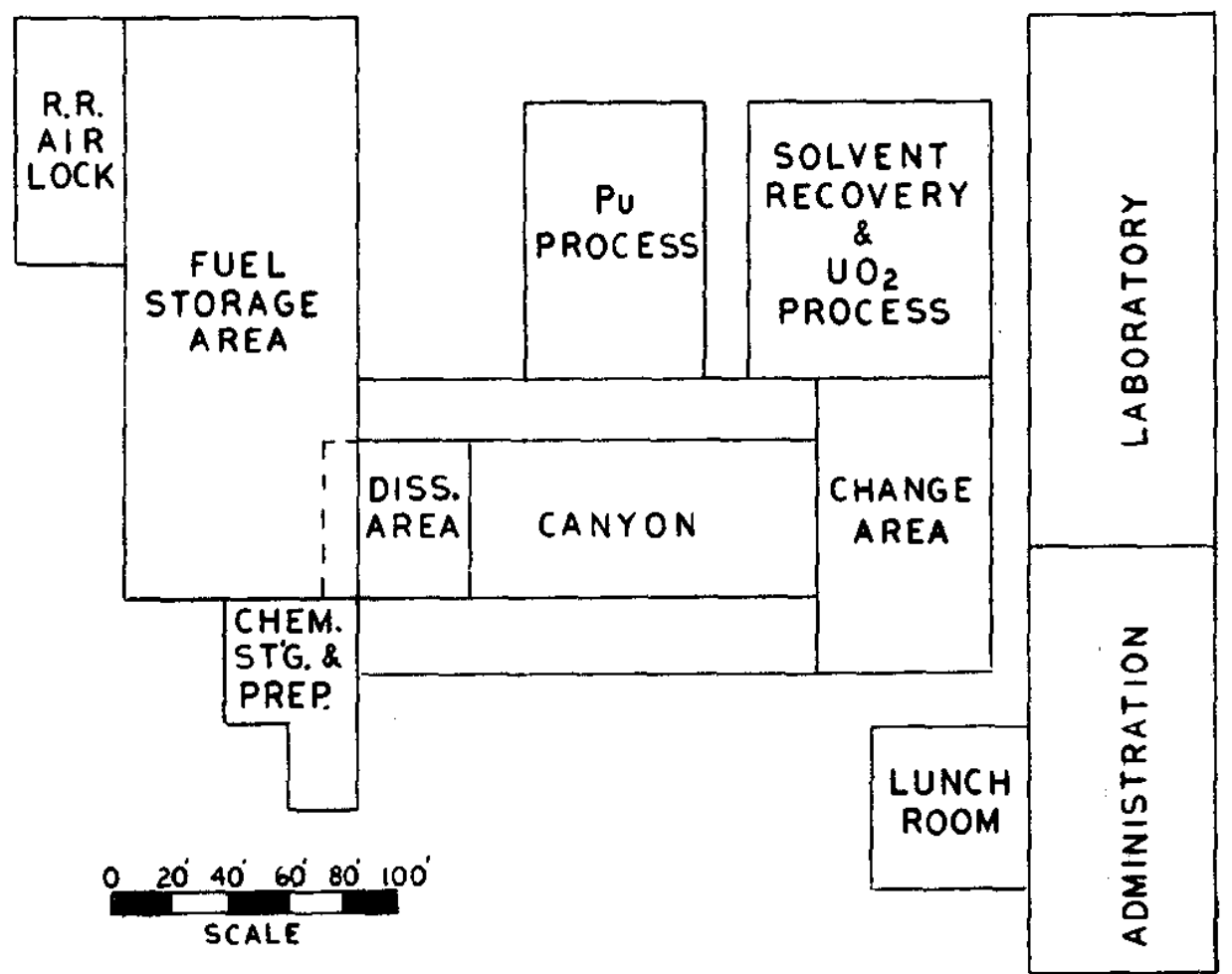

EXHIBIT 13 CASE VII - BUILDING NO. 13 - BUILDING ARRANGEMENT 
1. Engineering Design \& Inspection Design
Adminstrative Expense \& Inspection

- Construction Costs

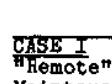

Malntenance

$5,100,000$
$6,500,000$
$6,600,000$

General Grading, Roads, Parking
Area, Railroads, Fence, Walks,

B. Butldings

Buldings
Fuel Element Receipt \& Storage
Fuel Element Basin Water Treatment

Separations
Plutonium Solution Processing

Laboratories

Decontamination Solution Storage
Chemical Storage \& Cold Feed Prep.
Solvent Purtf Ac1d Recov., G.P.

Solvent Phrtf. Acid Recov., G.P* .
Bvap. \& U Soin. Proe.

Evap. \& U Soln. Proe Administration

Shop, Warehouse, Change House,

C. Other Structures

D. Utilities Sewers, Culverts
Steam, Weter, Air, Effluent, De
laying Basin Pre Protect1 on
Electric Substations, Grounding

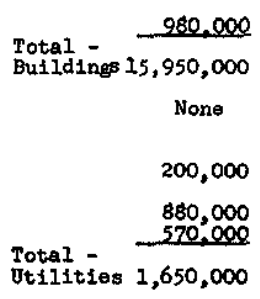

None

200,000

880,000

Total -

E. Equipment
Fuel Element Recelpt \& Storage
Fuel Element Basin Water Treat.

Fuel Element Basin Water Treat.
Separations
Plutonium Solution Processing

Plutonium Solution Processing
Laboratories
Chemical Storage \& Cold Feed Prep. Chemical Storage \& Cold Feed Prep.
Decontanination Solution Storage.
Solvent Wash. Acid Rec., G.P. Evap. $\&$ U Soln. Proc.

Service Buildings

o.s. Vent. Duats, Fans, Sand Filter, Stac

Non-Operating Equipment

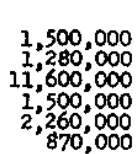

$3,500,000$

$1,040,000$
$4,150,000$

750,000
750,000

$32,400,000$

Equi potant Construction costal

3. Contingencies

$50,400,000$

$3,000,000$

Total Project cost

$60.000,000$

$\mathrm{U} / \mathrm{AI}-10 \mathrm{Ton} / \mathrm{Da}$
$\frac{\text { CASE II }}{\text { Contact" }}$
Ma1ntenance

$5,900,000$
$\frac{1,800 ; 000}{7,700,000}$

"Limited"

$4,950,000$
$\frac{1}{6,200,000}$
$6,150,000$

400,000

400,000

$3,450,000$

$13,500,000$

$1,100,000$
100,000

980,000

980.000

$21,650,000$

None

200,000

880,000
570,000
$1,60,000$

$1,650,000$

$3,450,000$

$6,850,000$
$1,390,000$

$1,100,000$
100,000

980,000

980,000

$25,400,000$

None

200,000

$\begin{array}{r}880,000 \\ 570,000 \\ \hline 1,650,000\end{array}$

$1,650,000$

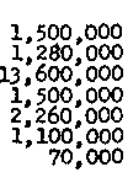

$1,500,000$
$1,280,000$

$1,280,000$
$10,900,000$
$1,500,000$

, 100,000

$3,500,000$
$1,040,000$

$3,500,000$

3,900,000

$35,100,000$

$58,800,000$

$3,500,000$

$20,000.000$

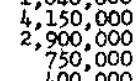

$31,350,000$

$48,800,000$

$3,050,000$

EXHIBIT 14 COMPARISON OF ESTIMATED COSTS 